\title{
PEMANFAATAN BANTUAN LUAR NEGERI DALAM PENINGKATAN EKONOMI KERAKYATAN TANI KAKAO DI PROVINSI SULAWESI BARAT (Studi Program Swisscontact Periode 2013-2018)
}

\author{
*(Wandi Abbas ${ }^{1}$, Abid Muhtarom ${ }^{2}$ \\ ${ }^{a}$ Master of Airlangga University Studies, University of West Sulawesi,wandiabbas13@gmail.com \\ ${ }^{(b)}$ Doctoral Studies of Airlangga University, Lamongan Islamic University,abid@unisla.ac.id
}

\begin{abstract}
Swisscontact is a private and independent Swiss foundation that promotes sustainable economic growth in developing countries. Founded in 1959, Swisscontact works exclusively in international cooperation and development and implements their own projects as well as trustees. The Swisscontact headquarters are in Zurich and have a close relationship with the private sector from the start. Swisscontact has prinspi that treats all people served and all partners with respect. In addition, Swisscontact also respects the workplace environment and complies with the rules of conduct well. (Swisscontact.org; 2017)

One of the problems considered important in analyzing a phenomenon in international relations is the level of analysis. Bruce Russett and Harvey Starr offer six levels of analysis: individuals (individuals), individuals (in decision-making roles), government structures, communities, decision-making networks and world systems. This research will use community analysis unit because this unit of analysis is the most competent in this research with qualitative method.

The implementation of the Swisscontact training program also encountered several obstacles such as; farmers, timetable arrangement of other farmers activities with the implementation of the same field school. While from Swisscontact, access to training loops is very difficult, the weather in the working area is changing so that the provision of training materials is less than the maximum. The influence of development and increase of export of Indonesian cocoa products especially West Sulawesi in recent years has increased significantly especially in the year 20142018. One of them is because the implementation of Swisscontact program in some regions of Indonesia province has given maximum result so that it has an effect to increase the production and export of Indonesian cocoa beans overseas.
\end{abstract}

Keywords: swisscontact program, international private investment, kakako export, people economy

\section{PENDAHULUAN}

Pada saat ini pula, politik dunia tidak bisa dipahami lagi hanya sebatas melalui satu perpekstif saja, studi hubungan internasional tidak cukup bila hanya membahas soal politik tanpa mempelajari ekonomi.Maka dari itu, dikarenakan keterkaitan antara ekonomi (kesejahteraan) dan politik (kekuasaan) inilah sehingga dikenal dalam hubungan internasional sebagai ekonomi politik internasional.
Ekonomi Politik Internasional (EPI ) didefinisikan sebagai studi tentang saling hubungan antara ekonomi dan politik dalam arena internasional. (Mochtar Mas'oed; 2008)

Salah satu jenis dari pelaksanaan ekonomi politik internasional yaitu bantuan luar negeri. Bantuan luar negeri menjadi instrument dalam pencapaian suatu pembangunan ataupun pertumbuhan dengan dibantu oleh pihak lain seperti negara 
ataupun organisasi. Bervariasi jenis bantuan yang ada dan diberikan termasuk kepada Indonesia.Bagi negara-negara yang belum/tidak mampu menghimpun tabungan domestik secukupnya untuk mendorong pertumbuhan ekonominya biasanya mencari sumber pembiayaan dari negara - negara lain. Bahkan negara maju seperti Amerika Serikat pun pernah sangat tergantung pada bantuan dana dari luar negeri, terutama pada periode $1835-1860$.

Aliran-aliran konsesional tersebut secara teknis disebut bantuan pembangunan resmi atau Official Development Assistance (ODA), tetapi lebih dikenal sebagai bantuan luar negeri. Bantuan ini dapat dibagi lagi atas bantuan bilateral, yang diberikan langsung oleh sebuah negara kepada negara yang lainnya dan bantuan multilateral, dimana dana-dana mengalir ke sebuah perwakilan internasional seperti PBB, Bank Dunia, dan bank-bank pembangunan regional, yang selanjutnya meminjamkan atau menyalurkan dana-dana tersebut ke negara sedang berkembang penerima. Akhirnya, bantuan luar negeri tersebut dapat terbentuk bantuan teknis, pemberian tenagatenaga terampil/ahli; atau bantuan modal, pemberian dana atau komoditi - komoditi untuk berbagai tujuan.

Kehadiran bantuan internasional dianggap sebagai sebuah instrument kebijakan sejak adanya kepentingan luar negeri yang tidak dapat di amankan dengan penanganan militer dan untuk mendukung metode diplomacy yang sebenarnya "tradisional" namun dalam bungkus yang lebih pantas. Selain kegunaan bantuan internasional sebagai instrument untuk mendukung tujuan kebijakan luar negeri, dalam prakteknya muncul bahwa kebijakan bantuan luar negeri meng-cover pula banyak disparitas tujuan dan kegiatan, sebagai respon dari berbagai macam kebutuhan, yang terlihat maupun yang tidak terlihat, berhubungan maupun tidak berhubungan pada tujuan politik sebuah kebijakan luar negeri.

Bantuan luar negeri juga dapat dianggap dapat mempermudah dan mempercepat proses pembangunan, karena bantuan luar negeri dapat secara seketika meningkatkan persediaan tabungan domestik sebagai hasil dari meningkatnya laju pertumbuhan yang ingin dicapai. Bantuan luar negeri cenderung dianggap atau bahkan diyakini akan dapat melengkapi kelangkaan sumber daya alam negeri di suatu Negara Berkembang, membantu terlaksannya transformasi ekonomi secara struktural, serta mendukung Negara - negara Dunia Ketiga dalam mencapai tahapan pembangunan tinggal-landas menuju ke tingkat pertumbuhan ekonomi yang berkesinambungan (siscaporina.com; 2012). Wajar apabila negara - negara Dunia Ketiga ingin memperoleh bantuan yang lebih banyak dalam bentuk pemberian yang cumacuma atau pinjaman-pinjaman jangka panjang dengan bunga yang rendah.

Bantuan luar begeri saat ini bukan hanya mengalir pada negara sebagai aktor utama saja dalam memenuhi kepentingan nasional, tapi bantuan luar negeri sudah langsung menyentuh pada pemerintahan di daerah mengingat peraturan otonomi daerahUndang-Undang no.32 tahun 2004 tentang pemerintah daerah mengisyaratkan perlu dilakukannya penyesuaian kewenangan pelaksanaan hubungan dan kerjasama luar negeri merupakan kewenangan pemerintah pusat. Namun seiring dengan berlakunya undang-undang otonomi daerah tersebut, kebijakan luar negeri dan diplomasi oleh pemerintah pusat antara lain juga diarahkan untuk memberdayakan dan mempromosikan potensi daerah dalam kerangka negara 
kesatuan repoblik Indonesia (fh.unsoed.ac.id; 2010).

Perubahan paradigma kerjasama luar negeri tersebut melalui undang undang otonomi daerah, maka pemerintah daerah akhir-akhir ini dengan leluasa membuka akses kerjasama dengan pemerintah daerah yang ada diluar negeri, baik melalui kerjasama sister city/province yang akhirnya mampu membuka investor bahkan bantuan luar negeri baik berupa hutang maupun hibah.Pada mulanya kewenangan ini diatur secara ekspilisit dalam ketentuan pasal 18 UU No. 22 tahun 1999 tentang pemerintah daerah. Namun karena dalam perkembangannya, pelaksanaan pasal 18 Undang-Undang tersebut cenderung mengarah kepada pemerintah bagian, sebagaimana praktek dalam negara-negara federal, maka kemudian dalam UndangUndang No. 32 tahun 2004 kewenangan daerah tersebut tidak disebutkan secara eksplisit lagi (Law UII.ac.id; 2015).

Berdasarkan peraturan diatas kemudian mulai membuka peluang bagi masuknya bntuan luar negeri dimana kepala daerah langsung yang menyambut bantuan tersebut.Diantara beberapa daerah yang sudah membuka kerjasama bahkan mendapat bantuan luar negeri berupa hibah adalah Sulawesi Barat.Provinsi Sulawesi Barat memliki sumber daya alam (SDA) baik didarat maupun dilaut seperti pertanian, perkebunan, kehutanan, peternakan, perikanan dan kelautan pertambangan dan pariwisata.Dari semua potensi yang ada dapat dikatakan sampai saat ini belum tergarap secara optimal karena keterbatasan baik dari sumber daya manusia maupun sarana prasarana yang belum memadai. Tentunya jika potensi-potensi tersebut dikelola dengan baik yang ditunjang dengan sarana dan prasarana infrastruktur yang memadai akan mampu memperbaiki kondisi ekonomi dan sosial di Sulawesi Barat.

Swisscontact merupakan sebuah yayasan swasta dan independen dari Swiss yang mempromosikan pertumbuhan ekonomi yang berkelanjutan di negaranegara berkembang.Didirikan pada tahun 1959, Swisscontact bekerja secara eksklusif dalam kerjasama dan pengembangan internasional dan menerapkan proyek mereka sendiri dan juga amanah.Kantor pusat Swisscontact berada di Zurich dan menjalin hubungan erat dengan sektor swasta sejak awal.Swisscontact memiliki prinspi yang memperlakukan semua orang yang dilayani dan semua mitra dengan hormat.Selain itu, Swisscontact juga menghormati lingkungan tempat bekerja dan mematuhi peraturan perilaku dengan baik. (Swisscontact.org; 2017)

Swisscontact berusaha untuk
profesionalisme dan kualitas dalam pelaksanaan proyek dan fokus pada prinsipprinsip etika untuk mencapai misi.Swisscontact memastikan kepatuhan terhadap persamaan hak dan persamaan kesempatan.Swisscontact membuat pembangunan berkelanjutan menjadi tujuan utama kegiatan proyek dan mengukur hasil kerja dengan standar dan metode yang diakui secara internasional.Swisscontact mempromosikan pembangunan ekonomi, sosial, dan lingkungan dengan mendukung orang-orang dalam usaha mereka untuk mengintegrasikan ke dalam kehidupan ekonomi lokal dengan mengembangkan ketrampilan mereka untuk mendapatkan pekerjaan atau memulai bisnis.Swisscontact bertindak sebagai fasilitator dalam pelaksanaan proyek dengan mendukung penciptaan lingkungan kewirausahaan dan akses terhadap informasi, keterampilan, dan pasar. 
Di provinsi Sulawesi Barat, Swisscontact telah melakukan berbagai kegiatan dan kerjasama dengan berbagai instansi dalam pelaksanaan proykenya.Swisscontact telah ada sejak tahun 2011 dan program kerjasama tahap ini akan berlanjut hingga pada tahun 2018 mendatang. Berbagai hal yang dilakukan ialah mengadakan pelatihan di masyarakat, edukasi dalam pemanfaatan wilayah dan lingkungan sekitar untuk lahan produktif, memberikan pengadaan bibit kakao kepada para petani, memberikan pelatihan tentang tatacara pemeliharaan yang baik dan lain sebagainya.Hal ini tentu memiliki manfaaat bagi para peningkatan hasil produksi kakao di Sulawesi Barat dan dapat meningkatkat taraf perekonomian masyarakat khususnya para petani.Selain itu, dengan konsistensi dari Swisscontact, tentunya sebagai salah satu wilayah produksi kakao, sulbar tentunya adapat meningkatkan hasil ekspor kakao untuk negara-negara produksi bahan kakao khususnya negara Swiss sebagai pengolah kakao terbesar dunia.

\section{KAJIAN PUSTAKA}

Nasir Badu (2015), telah melakaukan riset mengenai bantuan luar negeri di Sulawesi Barat. Dalam penelitiannya Badu memaparkan tentang pemanfaatan bantuan luar negeri di Sulawesi Barat yang lebih membahas pada berbagai jenis dan bantuan luar negeri yakni dari UNHCR, WISMP, MCA-I. Badu melihat bahwa berbagai bantuan luar negeri tersebut telah dimanfaatkan dan dikelola dengan cukup baik oleh pemerintah daerah sebagai penanggungajwab bantuan. Selain itu, dalam penelitiaannya tersebut Badu juga memaparkan tentang evaluasi bantuan luar negeri di Sulawesi Barat. Ia menjelaskan bahwa Sulawesi Barat telah cukup banyak menerima berbagai jenis bantuan luar negeri namun dalam pemanfaataannya masih terdapat beberapa hal yang menjadi bahan evaluasi. Yakni mislanya bantuan luar negeri yang dikelola oleh pemerintah Sulawesi Barat cenderung lamban dalam pendistribusiannya ke masyarakat. Hal ini dikarenakan terlalu rumit nya berbagai proseudr di birokrasi. Selain itu, setelah bantuan diberikan kemasyrakat, pemerintah hanya memberikan namun pengawasan dilapangan minim. Sehingga penyaluran bantuan tersebut kurang efektif atau tepat sasaran.

Hal yang membedakan dengan penelitian ini ialah terletak pada fokus yang menjadi subjek penelitian. Jika dalam penelitian sebelumnya berfokus pada berbagai aspek, maka penelitian ini hanya memfokuskan pada aspek pertanian yakni dalam hal ini terfokus pada perusahaan swasta yang menyalurkan bantuan luar negeri di Sulawesi Barat. Selain itu jika dala penelitian sebelumnya memfokuskan pada pemerintah sebagai pengelola dan penyalur bantuan luar negeri, maka dalam penelitian ini terfoku pada masyaraka sebagai penerima bantuan langsung. Dimana program dan bantuannya langsung dikelolah oleh pihak swasta dalam hal ini Swisscontact untuk disalurkan langsung kepada masyarakat dengan bentuk pelatihan, penyediaan bibit kakao sdan lain sebagainya.

Ekanayake (2010), dalam penelitiannya telah menganalisis dampak bantuan luar negeri terhadap pertumbuhan ekonomi negara-negara berkembang. Studi ini menggunakan data tahunan pada sekelompok 85 negara berkembang yang meliputi Asia, Afrika, dan Amerika Latin dan Karibia untuk periode 1980-2007. Dalam penelitiannya Ekanayake memaprkan bahwa bantuan luar negeri dapat mendorong pertumbuhan di negara-negara berkembang dieksplorasi, ini diuji dengan menggunakan rangkaian data panel untuk bantuan luar negeri, sementara memperhitungkan 
perbedaan regional di negara-negara Asia, Afrika, Amerika Latin, dan Karibia serta perbedaan tingkat pendapatan. Sementara temuan penelitian sebelumnya umumnya dicampur, hasil penelitian ini juga menunjukkan bahwa bantuan luar negeri memiliki dampak yang beragam terhadap pertumbuhan ekonomi di negara-negara berkembang.

Peran bantuan asing dalam proses pertumbuhan negara berkembang telah menjadi topik perdebatan sengit. Bantuan luar negeri merupakan topik penting mengingat implikasinya terhadap pengurangan kemiskinan di negara-negara berkembang. Studi empiris sebelumnya mengenai bantuan luar negeri dan pertumbuhan ekonomi menghasilkan hasil yang beragam. Walaupun Burnside dan Dollar (2000) menyimpulkan bahwa bantuan luar negeri memiliki dampak positif, kesimpulan ini hanya berlaku untuk ekonomi dimana dikombinasikan dengan kebijakan fiskal, moneter, dan perdagangan yang baik. Sebuah studi baru-baru ini oleh Doucouliagos dan Paldam (2009), ditemukan bahwa efek bantuan terhadap perkiraan pertumbuhan tersebar jauh dan menambah positif kecil, namun tidak signifikan berpengaruh terhadap pertumbuhan.

Peran utama bantuan luar negeri dalam mendorong pertumbuhan ekonomi adalah untuk melengkapi sumber pembiayaan dalam negeri seperti tabungan, sehingga meningkatkan jumlah investasi dan persediaan modal. Seperti yang Morrissey (2001) tunjukkan, ada sejumlah mekanisme yang memungkinkan bantuan membantu pertumbuhan ekonomi, termasuk (a) bantuan meningkatkan investasi, modal fisik dan manusia; (B) bantuan meningkatkan kapasitas untuk mengimpor barang modal atau teknologi; (C) bantuan tidak memiliki efek tidak langsung yang mengurangi tingkat investasi atau tabungan; Dan bantuan dikaitkan dengan transfer teknologi yang meningkatkan produktivitas modal dan mendorong perubahan teknis endogen. Menurut McGillivray, dkk. (2006), empat pandangan alternatif utama mengenai efektivitas bantuan telah disarankan, yaitu, (a) bantuan memiliki tingkat pengembalian yang berkurang, (b) efektivitas bantuan dipengaruhi oleh kondisi eksternal dan iklim, (c) efektivitas bantuan dipengaruhi oleh kondisi politik, Dan (d) efektivitas bantuan tergantung pada kualitas kelembagaan.

\section{METODE}

Salah satu masalah yang dianggap penting dalam menganalisa suatu fenomena dalam hubungan internasional adalah tingkat analisis (level of analysis). Bruce Russett dan Harvey Starr menawarkan enam tingkat analisis: individu (personal), individu (dalam peran sebagai pembuat keputusan), struktur pemerintah, masyarakat, jaringan pembuat keputusan dan sistem dunia. Penelitian ini akan menggunakan unit analisis masyarakat karena unit analisis ini merupakan yang paling berkompeten dalam penelitian ini.

Disamping itu, analisis data dilakukan melalui proses penyederhanaan data ke dalam bentuk yang lebih mudah dibaca dan diinterprestasikan. Dimana, analisis ini dilakukan secara kualitatif yang bertujuan membuat penjelasan secara sistematis, faktual, akurat mengenai faktafakta, sifat dan fenomena yang diteliti melalui studi dokumentasi, obsevasi dan wawancara yang mendalam dari para informan untuk mendalami kasus ini.

\section{PEMBAHASAN}


Swisscontact merupakan yayasan independen yang berorientasi pada bisnis untuk kerjasama dalam pembangunan internasional.Sesuai dengan misinya bahwa perhatian utama Swisscontact ialah terbagi dalam berbagai bidang yakni; ekonomi, lingkungan dan sosial.Swisscontact mempromosikan pembangunan ekonomi, sosial, dan lingkungan dengan mendukung orang-orang dalam usaha mereka untuk mengintegrasikan ke dalam kehidupan ekonomi lokal dengan mengembangkan keterampilan mereka untuk mendapatkan pekerjaan atau memulai bisnis.Swisscontact bertindak sebagai fasilitator dalam pelaksanaan proyek dengan mendukung penciptaan lingkungan kewirausahaan dan akses terhadap informasi, keterampilan, dan pasar untuk membantu menciptakan kondisi kerja dan menghasilkan (Swisscotact.org; 2017)

pendapatan.

Sejak awal Program SCPP, saat ini Program telah berkembang menjadi program yang berdampak tinggi dan pengembangan dengan jangkauan yang luas yang memenuhi tujuan pembangunan dari donor dan tujuan dari mitra sektor swasta. Menciptakan lingkaran kebajikan (virtuous cycle) dari praktik pertanian yang akan meningkatkan keuntungan dan kesejahteraan dan mengarah ke penerapan cara bertani, perbaikan gizi dan pengelolaan keuangan petani yang lebih baik. Program ini telah menjadi nilai standar, bukan saja di Indonesia, namun di seluruh dunia untuk pendekatannya, metodologi, dan yang paling penting, dampak terhadap keluarga petani.Secara rinci, Program ber-evolusi dalam tiga tahap perkembangan dengan tahap keempat yang direncanakan di mulai pada April 2016. Diantaranya; 2010-2012 tahap pertama (12.000 petani di 5 kabupaten), 2012-2015 tahap kedua $(60.000$ petani di 19 kabupaten), 2015-2018 tahap ketiga (98.000 petani di 29 kabupaten), 2016-2020 tahap keempat (130.000 petani di 50 kabupaten).

PEKA (2010-2012): Swisscontact menerima pendanaan dari Economic Development Facility (EDFF), dikelola oleh World Bank, berdasarkan dari pengalaman Swisscontact di proyek sebelumnya di Indonesia bagian timur dan Sumatera Utara untuk memperluas kegiatan kakao di 5 kabupaten di Aceh untuk memberi manfat kepada 12.000 petani. SCPP SECO (20122015): SCPP dimulai secara resmi pada tanggal 1 Januari 2012, sebagai kelanjutan dari Peningkatan Ekonomi Kakao Aceh (PEKA) di Aceh, berkembang ke Sulawesi. CPQP 1-IDH (2012-2015): Tiga perusahaan swasta menyatakan minat mereka untuk bekerja sama dengan Swisscontact di Sulawesi, yang pada akhirnya IDH berdiri sebagai mitra dana tambahan ke SECO.

STMF-IDH and CPQP2-IDH (20122015): Komitmen lebih lanjut dari IDH adalah menambahkan dua perusahaan swasta dan memperluas jangkauan proyek ke Sulawesi. GNP-EKN (2012-2015): Desember 2012, the Embassy of the Kingdom of Netherlands (EKN) atau Kedutaan Belanda bergabung dengan Program dengan modul Praktik Gizi yang Baik (Good Nutrition Practices), menambahkan nilai yang besar untuk kegiatan-kegiatan Program dalam meningkatkan kesejahteraan petani. AFFSECO (2014-2016): Maret 2014, SECO memperluas komitmen kepada SCPP dengan mengintegrasi Agribusiness Financing Facility (AFF) atau Fasilitas Pembiayaan Agribisnis sebagai komponen untuk mefasilitasi Akses ke Keuangan, terutama tabungan dan pinjaman, kepada petani dan menyediakan pelatihan untuk meningkatkan kemampuan petani untuk mengelola keuangan pribadi mereka. 
Program Swisscontact di Sulawesi Barat telah berjalan sejak tahun 2010. Adapaun tempat lokasi yang menjadi concern program Swisscontact adalah Kabbupaten Mamuju, Mamasa, Majene dan Polewali Mandar. Pelaksanaan program terbagi dalam beberapa tahap program yakni tahun 2011 dimulai di kabupaten Majene dan Mamuju, Tahun 2013 untuk kabupaten Polewali Mandar dan tahun 2017 untuk wilayah kabupaten mamasa. Program Swisscontact berlangsung hingga 2020 mendatang. Dalam melakasanakan berbagai programnya, Swisscontact memiliki beberapa mitra baik lokal mupun nasiaonal, diantanya ialah: Millennium Challenge Account - Indonesia (MCA-I), Krakakoa dan Barry Callebaut.

\section{Capaian yang dihadapi Swisscontactdalam Pemanfaatan Bantuan di Sulawesi Barat.}

Program Swisscontact telah mencapai hasil yang maksimal. Hal tersebut terlihat pada keberhasilan peningkatan produksi kakao petani di Sulawesi Barat sejak 2010 hingga saat ini. Selain itu, capaian yang cukup penting dari program Swisscontact di Sulawesi Barat ialah berbagai program telah dilakukan kepada para petani, diantaranya ialah; pengenalan lingkungan, pemahaman tentang tanaman kakao berupa sekolah lapang serta praktik langsung yang didampingi oleh fasilitator, pengolahan dan penjualan biji hasil kakao yang telah tersertifikasi dari mitar Swisscontact. Selain itu, dengan program ini tentunya para petani mendapat pemahaman lebih tentang tanaman kakao serta dapat memanfaatkan lingkungan sekitar untuk meningkatkan mendapatan dengan penggunaan lahal kosong di sektar tempat tinggal petani.Adapun rangkaian kegiatan dan capaian dari programa Swisscontast di provinsi Sulawesi Barat ialah sebagai berikut:

\subsection{Kabupaten Polewali Mandar}

Kegiatan ini akan dilaksanakan selama 9 (sembilan) kali pertemuan,dimana FFS GAP Basic bagi 57 Kelompok tani dan FFS GEP bagi 41 kelompok tani pada 6 Kecamatan di wilayah Polewali Mandar. Materi pelatihan adalah Dasar Praktek budidaya kakao yang baik (GAP Basic) dan Praktek lingkungan yang baik (GEP). Sekolah Lapang GAP Basic akan difasilitasi oleh staf IMS Barry Callebaut dan Penyuluh bersama dengan Key Farmer yang telah mengikuti ToT GAP regular dan ToT Refresh,sedangkan Sekolah Lapang GEP akan difasilitasi oleh staf FF dan FC SCPP.

\subsubsection{Tujuan pelaksanaan Sekolah Lapang ini adalah sebagai berikut:}

- Meningkatkan pengetahuan dan keterampilan teknis budidaya tanaman kakao dalam rangka meningkatkan produksi dan mutu kakao bagi petani penerima manfaat dari proyek $G P$ $S C P P$;

- Meningkatkan ketrampilan teknis petani dalam mengadopsi praktek pertanian yang baik dalam mengelola usahatani kakaonya

- Membantu dan memonitor kegiatan petani/kelompok tani dalam penerapan praktek-praktek budidaya terbaik (GAP).

- Meningkatkan pengetahuan dan pemahaman serta kesadaran tentang Lingkungan (Keberlanjutan,Ekosistem dan perubahan lingkungan)

- Mempromosikan praktek ramah lingkungan di kebun kakao;

- Meningkatkan pemahaman tentang hubungan antara Komponen lingkungan dengan komunitas lingkungan.

\subsection{Kabupaten Mamasa}


Dimulai pada January 2017, GPSCPP bekerjasama dengan PT. Aneka Coklat Kakoa (Krakakoa) mengembangkan kakao organik di tiga desa di kabupaten Mamasa, yakni Saludengen, Masoso, dan Rantai Terima. Target utamanya adalah sertifikasi organik sehingga penerapan GAP dan fermentasi biji kakao-nya akan mengikuti praktek pada pola pertanian organik. Skema pendanaan program mengikuti pola pembagian berikut: 1) Periode January 2017 hingga Maret 2018 berasal dari SECO dan MCA (GP-SCCP); dan 2) Periode April 2018 hingga December 2020 berasal dari SECO (SCPP). Program ini juga akan dihubungkan dengan aktifitas Koltiva yang diharapkan dapat mendukung pada management information system yang mencakup data dan penyimpanannya, pelatihan terkait sertifikasi, termasuk internal inspection sebelum dilakukan External Audit oleh lembaga sertifikasi yang akan di tentukan kemudian.

Adapun Scope dari Program tersebut ialah; Pertanian Organik (organic farming): Petani kakao penerima manfaat program ini akan dilatih teknik pertanian organik yang mengedepankan GAP, manegement hama dan penyakit secara organik, pembuatan kompos organik, pembuatan pupuk organik, dll. Fermentasi biji dan pengeringan: Kegiatan fermentasi biji dan pengeringannya tidak dilaksanakan oleh keseluruhan petani target. Namun kegiatan ini akan diserahkan dibawah kendali Pak Alek (sebagai KF) yang akan dibantu oleh beberapa orang petani. Untuk itu, tidak perlu untuk melatih keseluruhan petani target dengan materi fermentasi biji dan pengeringannya.Pembibitan dan Clonal Garden: Program ini juga mencakup pembangunan pembibitan tanaman kakao (Seedling Nursery) dan clonal garden. Krakakoa akan menugaskan seorang konsultan untuk menangani bagian pekerjaan ini. Petani yang akan dilatih; Total berjumlah 250 petani yang akan dilatih didalam 2 siklus pelatihan pada tahun 2017 . Dan Para petani akan diseleksi dari desa Saludengen, Masoso, dan Rantai Terima yang diharapkan dalam jumlah yang berimbang.

\subsection{Kabupaten Mamuju}

Nestle- Cocoa plan bekerjasama dengan Swisscontact - SCPP untuk memperkuat kapasitas pengelolaan perkebunan kakao rakyat dan bantuan teknis kepada organisasi petani di kabupaten Mamuju, Sulawesi Barat. Program ini menyediakan pelatihan bagi petani, distribusi klon terbaik, mendukung trasnparansi pada 'pasokan dan emmbanagun fasilitas percobaan daan demonstrasi pertanian kakao.Program ini memperkenalkan pendekatan tiga dimensi people, prrofit and planet (dimensi sosial, ekonomi dan lingkungan) secara menyeluruh melalui pelatihan untuk petani kakao dan kerjasama yang erat dengan pemerintah kabupaten mamuju serta program produksi kakao berkelanjutan (PPKB). (Swisscontact.org; 2017)

Dimensi Ekonomi, Program ini bekerja sama dengan Pemerintah Indonesia dan swasta untuk meningkatkan produktivitas dan keuntungan usaha kakao. Pengembangan sektor kakao membutuhkan peningkatan kapasitas dari para pemangku kepentingan di setiap rantai nilai dan pasokan.Untuk itu, Dimensi ini memperhatikan paket pelatihan keterampilan demi menghasilkan petani profesional (input pertanian, bahan tanam, teknik budidaya kakao), peningkatan akses layanan dan permodalan, pembinaan pengembangan usaha, serta wadah tukar informasi dan dialog. Dimensi Lingkungan, Pemerintah Indonesia serta donor turut prihatin dengan memburuknya kondisi iklim dan kurangnya praktik ramah 
lingkungan yang diterapkan petani kakao di Indonesia. Jika dampaknya tidak segera ditangani, produksi kakao bisa terganggu selain nilai guna lahan pertanian kakao pun menurun. Program ini mendorong penerapan teknik pertanian ramah lingkungan di beberapa wilayah di Indonesia. Selain itu, Program ini mengembangkan kerangka kerja untuk mengukur nilai konservasi pertanian kakao.Tujuan utamanya adalah untuk meningkatkan kesadaran terhadap persoalan lingkungan di sektor kakao dengan mendidikdan melatih petani mengenai praktik-praktik ramah lingkungan.

Dimensi Sosial, Masih rentannya petani kakao terjerumus kedalam kondisi sosial yang buruk, menjadikannya tidak cukup meningkatkan pendapatan para petani saja. Misalnya, datam upaya membantu mengatasi masalah gizi buruk dii rumah tangga petani, SCPP memberikan pelatihan untuk memudahkan akses masyarakat kepada sumber makanan bergizi dan layanan dasar lainnya. Selain itu, Program ini melibatkan kelompok marjinal seperti perempuan dan kaum muda kedalam program pendidikan serta meningkatkan kemampuan masyarakat dalam kehidupan sosial mereka.

Hasil biji kakao yang berkualitas dari para petani bukan hanya di jual dalam bentuk biji namun diolah menjadi akanan coklat kakao dengan kualitas terbaik. Salah satunya ialah mitra Swisscontact dalam hal ini Krakakoa memproduksi coklat batang dari kakao para petani binaan dari swisscontact kemudian diual kepasaran dan diekspor keberbagai negara. Selain itu benefit dari pelatihan program ini bagi para petani ialah produk jadi coklat dari desaa salidengen sulawesi barat berhasil memperoleh penghargaan di ajang academy cocoa tahun 2017 kategori treeto bar. Hal ini tentunya menjadi bukti bahwa keberhasilan dan pemanfaaatan dari program ini cukup maksimal yang menjadikan hasil kakao par petani di sulawesi barat semakin berkualitas dan menjadai kakao yang layak ekspor keberbagai negara

\section{Kendala yang dihadapi Swisscontactdalam Pemanfaatan Bantuan di Sulawesi Barat.}

Dalam pelaksanaan program swisscontact yang dilakukan di provinsi sulawesi barat juga menghadapi berbagai tantangan dan kendala. Hal ini tentunya berbpenngaruh terhadap maksimalitas pelaksanaan prgram di lapangan. Adapaun berbagai kendala tersebut ialah; Petani, petani merupakan target dan objek pelaksanaan program ini namun selama dalam pelaksanaan program petani meghadapi beberapa kendala sperti sulitnya mengatur jadawal pelatihan dan sekolah lapang dengan jadwaal kebiasaan para petani sehingga waktu yang ditargetkan dalam pelatihan masih kurang. Selaian itu, sebgaian dari para petani memiliki keterbatasan dalam penerimaan materi yakni tidak paham membaca dan menulis sehingga hal ini juga menjadi salah satu kendala mereka auntuk memperoleh pengetahuan yang maksimal.

Swisscontact, kendala dan tantangan yang dihadapi oleh pihak Swisscontact selaku pelaksana program di sulawesi barat, diantaranya ialah; akses ke lokasi pelatihan sangat sulit dijangkau dengan kendaraan. Kemudian kondisi cuaca yang kurang mendukung menjadikan waktu rencana pelkasanaan program terganggu sehingga pemberian materi kepda para petani kurang maksimal.selain itu kehadiran para petani disetiap hari pada pelatihan sekolah lapang yang kurang maksimal menjadikan pemaparan materi kepada para petani kurang maskimal ataua dalam hal ini tidak sesuai 
target. Hal ini dikarenakan penyesuaian jadwal lain petani dengan waktu sekolah lapang terjadi secara bersaamaan.

\section{Pengaruh program Swisscontact terhadap peningkatan produksi kakako Sulawesi Barat dan ekspor hasil tani kakako Indonesia ke luar negeri}

Produktifitas dan ekspor hasil kakao indonesia mengalami peningkatan, hal tersebut dapat dilihat pada data berikut yakni sejak tahun 2014 hingga 2016 hasil produksi kakao Indonesia mengalami peningkatan yang cukup maksimal. Disamping pemerintah cukup serius dalam produksi kakao undonesia yang maksimal juga keberhasilan dari pelaksanaan program Swisscontact di Indonesia sejak tahun 2010.Selain peningkatan jumlah biji kakao, hasil biji kakao Indonesia juga telah tersertifikasi yakni kakao yang termasuk dalam pelaatihan Swisscontact. Sehingga kualitas biji kakao Indonesia terjamin danalayak eskpor ke berbagai negara yang menjadi negara ekspor tujuan Indonesia. Berikut merupakan data persentasi hasil dan ekspor kakao indonesia keberbagai negara (data tahun 2014-2016).

\section{Tabel Luas Tanaman} Menghasilkan (TM) dan Produksi Kakao Menurut Provinsi dan Status Pengusahaan Sulawesi Barat Tahun 2014

\begin{tabular}{|c|c|c|c|c|c|c|c|c|}
\hline \multirow{2}{*}{ No. } & \multirow{2}{*}{$\begin{array}{c}\text { PROVINSI/KABUPATEN } \\
\text { Province/District }\end{array}$} & \multicolumn{4}{|c|}{ Luas Areal/Area (Ho) } & \multirow{2}{*}{$\begin{array}{l}\text { Produksi } \\
\text { Production } \\
\text { (Ton) }\end{array}$} & \multirow{2}{*}{$\begin{array}{c}\text { Produktivitas/ } \\
\text { Productivity } \\
(\mathrm{Kg} / \mathrm{Ha})\end{array}$} & \multirow{2}{*}{$\begin{array}{l}\text { Jumlah } \\
\text { Petani/ } \\
\text { Farmers } \\
\text { (KK) }\end{array}$} \\
\hline & & $\begin{array}{c}\text { TBM/ } \\
\text { Immature }\end{array}$ & $\begin{array}{l}\text { TM/ } \\
\text { Mature }\end{array}$ & $\begin{array}{l}\text { TTM/TR/ } \\
\text { Damaged }\end{array}$ & $\begin{array}{c}\text { Jumlah/ } \\
\text { Total }\end{array}$ & & & \\
\hline \multirow[t]{8}{*}{28.} & SULAWESI BARAT & & & & & & & \\
\hline & Kab. Polewali Mandar & 8.684 & 28.608 & 12.098 & 49.389 & 25.996 & 909 & 46.822 \\
\hline & Kab. Mamasa & 5.881 & 9.820 & 7.512 & 23.213 & 7.571 & 771 & 18.950 \\
\hline & Kab. Majene & 1.663 & 6.675 & 5.279 & 13.617 & 6.064 & 908 & 11.620 \\
\hline & Kab. Mamuju & 5.688 & 20.322 & 17.932 & 43.942 & 17.614 & 867 & 34.623 \\
\hline & Kab. Mamuju Tengah & 2.046 & 9.546 & 6.792 & 18.383 & 7.523 & 788 & 16.218 \\
\hline & Kab. Mamuju Utara & 2.370 & 9.388 & 8.089 & 19.847 & 7.269 & 774 & 14.798 \\
\hline & PROVINSI/PROVINCE & 26.332 & 84.357 & 57.702 & 168.391 & 72.037 & 854 & 143.031 \\
\hline
\end{tabular}

Sumber: Statistik Perkebunan Indonesia 2014-2016 Kakao, Direktorat Jenderal Perkebunan, Kementerian Pertanian, 2016

Tabel Luas Tanaman Menghasilkan (TM) dan Produksi Kakao Menurut Provinsi dan Status Pengusahaan Sulawesi Barat Tahun 2015

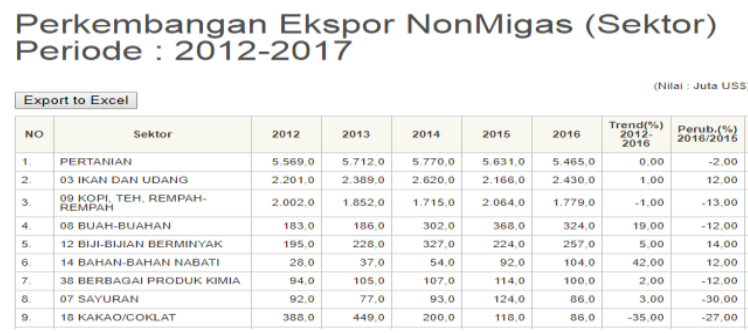

Sumber: Statistik Perkebunan Indonesia 2014-2016 Kakao, Direktorat Jenderal Perkebunan, Kementerian Pertanian, 2016

Tabel Luas Tanaman Menghasilkan (TM) dan Produksi Kakao Menurut Provinsi dan Status Pengusahaan Sulawesi Barat Tahun 2016

\begin{tabular}{|c|c|c|c|c|c|c|c|c|}
\hline 25. SULANES UTARA & 6.703 & 3.582 & 292 & 155 & 654 & 1.156 & 7.649 & \\
\hline GORONTALO & 3.600 & 2.536 & & & & & 3.600 & \\
\hline 27. SUAAWESTENGAH & 196.234 & 175.251 & & & 4 & 2 & 196.238 & \\
\hline 28. SULANESISEATAN & 141.014 & 114.258 & & & 2.186 & 1.068 & 143.200 & \\
\hline 29. SULAN & 94.496 & 75.713 & & & & & 94.496 & \\
\hline 30. SULAWES TENGGARA & 147.982 & 120.421 & & . & & & 147.982 & \\
\hline UAlA & 590,029 & 491.860 & . & 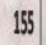 & 2844 & 2.226 & 593.165 & \\
\hline
\end{tabular}

Sumber: Statistik Perkebunan Indonesia 2014-2016 Kakao, Direktorat Jenderal Perkebunan, Kementerian Pertanian, 2016

Luas Areal dan Produksi Kakao

Perkebunan Rakyat Menurut Kabupaten dan Keadaan Tanaman Provinsi Sulawesi Barat Tahun 2014

\begin{tabular}{|c|c|c|c|c|c|c|c|c|}
\hline 25. SULAWES UTARA & 5.447 & 3.043 & 292 & 135 & 654 & 1.152 & 6.393 & 4,331 \\
\hline 26. GORONTALO & 3.143 & 2060 & & & & & 3.143 & 2.060 \\
\hline 27. SULAWESI TENGAH & 172593 & 153.031 & & & 4 & 1 & 172.597 & 153.033 \\
\hline 28. SULAWESI IELATAN & 123.909 & 99.798 & & . & 2.159 & 1009 & 126.068 & 100.807 \\
\hline 29. SULAWES BARAT & 80.483 & 65.667 & & & & & 80.483 & 65.667 \\
\hline 30. SULAWESI TENGGARA & 127.169 & 105.434 & & 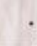 & & & 127,169 & 105,434 \\
\hline WILAYAHSULAWESI & 512.74 & 429.034 & 292 & 135 & 2817 & 2.162 & 515.853 & 431.331 \\
\hline
\end{tabular}



2016

Perkembangan ekspor sektor non migas periode 2012-2017 khusus sektor kakao sebagai berikut. Tahun 2012 bernilai US\$388,0 juta sedangkan di tahun 2013 mengalami peningkatan menjadi sebesar US $\$ 449,0$ juta. Di tahun 2014 mengalami penurunan menjadi sebesar US $\$ 200,0$ juta dan di tahun 2015 merosot kembali menuju angka US\$118,0 juta. Dan terakhir di tahun 2016 hanya bernilai sekitar US\$86,0 juta (Kemendag.go.id).

\begin{tabular}{|c|c|c|c|c|c|c|c|c|}
\hline 25. SULAWES UTARA & 5.869 & 3.281 & 292 & 149 & 654 & 1.153 & 6815 & 4.583 \\
\hline 26. GORONTALD & 3389 & 2890 & & & & & 3389 & 2890 \\
\hline 27. SULAESITENGAH & 177.728 & 161.467 & & & 4 & 2 & 17,732 & 161.469 \\
\hline 28. SULAWESI SELATAN & 145.434 & 117.306 & & . & 2.159 & 1023 & 147.593 & 118329 \\
\hline 29. SULANES BARAT & 84.357 & 72.037 & & & & & 84357 & 72037 \\
\hline 30. SULWESI TENGGARA & 146.874 & 125.079 & & & & & 1468.74 & 125.079 \\
\hline WILAYAHSULAWESI & 563.651 & 482.,061 & 292 & 149 & 2817 & 2.178 & 566.760 & 484.387 \\
\hline
\end{tabular}

Sumber: (Kemendag.go.id)

Negara tujuan ekspor kakao Indonesia terbesar adalah Malaysia dengan volume ekspor sebesar 105,25 ribu ton (US\$ 300,18 juta) pada tahun 2015. Negara tujuan ekspor kakao berikutnya adalah USA, Jerman, Cina, Belanda, Spayol, India, Australia, Philipina dan Thailand. Sementara ke negara lainnya Indonesia mengekspor kakao sebesar 84,37 ribu ton (Kementerian Pertanian, 2016).

\section{Ekspor Biji Coklat Menurut Negara Tujuan Utama, 2002-2015}

\begin{tabular}{|c|c|c|c|c|c|c|c|c|c|c|c|c|c|c|}
\hline hennits & 2002 & 2013 & 200 & 2015 & 206 & 207 & 2008 & 2018 & 2010 & 2011 & 2012 & 2013 & 2014 & 2015 \\
\hline & \multicolumn{14}{|c|}{ Beret tershtim } \\
\hline (x) & 435,8 & 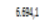 & 582.1 & sem. 1 & ans? & 2an!s & 135a, & 120,5 & 13399 & Bsy & 6921 & 150,2 & 500 & 603,3 \\
\hline$w$ & B.43, & 63,0 & 635? & seat & 180,4 & 13500 & 816,2 & 1265,5 & 1263 & : & Let & $17.13,4$ & 4975, & 1374 \\
\hline 0 & 5758, & 312,6 & 3150,3 & 30039 & 4005,5 & 13535 & 1515:5, & Then, & 5393 & $3 \mathrm{~s}=3$ & 4.5984 & 331469 & 2161,1 & 5350,0 \\
\hline als & 353 & 12428 & 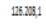 & 15931 & $\sin 3,1$ & 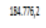 & 2400,3 & : & $20 \mathrm{~s}, \mathrm{n}$, & 103290 & 1033,1 & sant44 & 137300 & 32358 \\
\hline BSE & Horse, & \$0แ16 & uner, & $10.80,5$ & 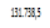 & $\$ 2324$ & 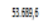 & masul & 80335,5 & 3.4, & 2.3 .3 & , & 249 & 1.8]: \\
\hline & 12.3 & 5250 & :0020 & 45000 & 11380 & $: 550,0$ & 13000 & 2200,3 & 13500 & 5.5000 & 2,5 & He? & 20,8 & 3, \\
\hline 6 & 465 & 19970 & 132800 & vas. & $E m$ & 340 & $\$ 50,0$ & 1800 & 4055 & 4950 & 51310 & $5 m 0$ & 780,1 & 55,0 \\
\hline sava & 3,3 & w.1. & 78, & 1007,5 & 20,4 & 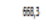 & 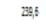 & 2025 & $5,50,5$ & 790 & $\sin 6$ & 107,5 & 87,5 & 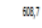 \\
\hline enter & 34 & 5518 & mo & teas & :5as, & 95,2 & sw, & 715,4 & 12385 & 23,8 & 垹 & 20,5 & mo, & 21013 \\
\hline ing: & s. & 12:4.1 & 1.28, & $130 \mathrm{a}$, & $n=0$ & axest & 31305: & asas, & $3 \mathrm{an}$, & 399 & 159,1 & 1249 & 7819,3 & 90508 \\
\hline \multirow[t]{2}{*}{ intile } & 30.5 & 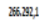 & 217.159, & 3850 & ans, & 3.5es & 32006,5 & WLE, ? & Ex:2023, & zutz:33 & D2106, & 20.5W, & 17.55, & 5220,4 \\
\hline & \multicolumn{14}{|c|}{ Mia freacoulus } \\
\hline (ogtox & 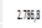 & 90256 & 19075 & 20009 & zasas & uss, & 335126 & 1004, & 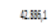 & 25039 & $19 m, t$ & asapo & 123,2 & 1201,6 \\
\hline ot & 356 & 1931.1 & 82,6 & bsul & 9142 & 959,4 & san: & tases: & IAn, & 02036 & way, & 2046 & $: 177,6$ & 4as, \\
\hline ma & : & 5005 & องมี & ans? & 51909 & 7uss: & mssy: & ans: & 151215? & sats & cassus & mos, & แ115, & $12 m, 5$ \\
\hline aja & 112309,1 & 263512 & 15009 & SQLA, & mase? & anses & man, 2 & 15LE: & "5Ha1:1 & .113541 & ans & 30728,8 & matas & $7280 ; 3$ \\
\hline 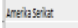 & sasp & mam & 12203,5 & 1352201 & 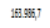 & was, & 2ass,4: & 2801,2 & 2654,3 & 20503 & 5a.1. & ses, & Las, & $12 \mathrm{z}, 4$ \\
\hline gad & 3 & 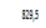 & (a) & 582, & 450,8 & 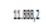 & nuent & 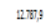 & 2455 & 57 & 15,0 & 50,1 & 826 & 240 \\
\hline 165: & 20038 & 3.2.4.1 & 2052 & 3525,5 & an7,8 & 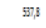 & L4, 3 & ASW, & 1072,2 & 14:320 & $112 m 9$ & $\operatorname{ses} 4$ & awa, & wo \\
\hline sata & 3 & $m$ & 828 & 1948 & 40552 & $1, \mathbb{2}, 2$ & 528 & 586,4 & 1558,6 & 2831 & 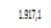 & 52,3 & $: 2111$ & 2064,1 \\
\hline 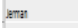 & 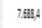 & 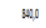 & $1 \mathrm{LB} ?$ & 4 & Batal, & IE, & 12, & 2 & 者, & LES1 & 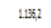 & 1.300 & $200 \% 1$ & 2084 \\
\hline alpt & wan? & 12sese & $12 m 5$ & 13590 & ux!s & ams & רom, & 20151,4 & 11629,5 & 165240 & 124, & 2049 & :20153 & $25: 3$ \\
\hline & salust, & encuse & 3028,4 & 428236 & 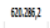 & 232017 & BSASE, & 1 19:13,4 & L19uss, & 60.9916, & 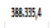 & 4ass, & mones & wase,s \\
\hline
\end{tabular}

Ket: Berdasarkan Keppres No.12/2014 tentang penggunaan kata Tiongkok untuk menggantikan kata Cina. Diolah dari dokumen kepabeanan Ditjen Bea dan Cukai (PEB dan PIB), Dikutip dari Publikasi Statistik Indonesia

\section{KESIMPULAN}

Program bantuan luar negeri Swisscontact telah berjalan sejak tahun 2010 di provinsi Sulawesi Barat, adapun daerah utama yang menjadi acuan program ialah kabupaten Polewali mandar, kabupaten mamasa dan kabupaten Mamuju. Adapun bentuk pmanfaatan dari program tersebut dianatanya ialah; pelatihan dalam bidang sosial,eknonomi, lingkungan yang terfokus pada petani kakao. Pelatihan tersebut dilakuakn bebebrapa tahap terhitung sejak tahun 2010 hingga pada tahun 2020 mendatang.Bentuk pelatihan dari program ini diantaranya; pemaparan materi tentang kakao atau pengenalan tentang tanaman kakao, pembuatan pestisida nabatai oleh petani, pembuatan pupuk organik, pemangkasana tanaman kakao, permentasi biji kakao, penjemuran seta pengolahan dan pengiriman hasil biji kakako.

Kemudian dalam pelaksanaan program pelatihan Swisscontact juga mengalami beberapa kendala diantaranya; petani, pengaturan jadwal waktu aktifitas lain petani dengan pelaksanaan sekolah lapang yang bersamaan. Sedangkan dari Swisscontact, akses menuju loaksi pelatihan yang sangat sulit, cuaca di wilayah kerja yang berubah-ubah sehingga pemberian materi pelatihan kurang maksimal.Adapun pengaruh perkembangan dan peningkatan ekspor hasil kakao Indonesia khsusunya Sulawesi Barat dalam beberapa tahun terakhir mengalami peningkatan yang cukup 
signifikan khususnya pada tahun 20142016.Salah satunya karena pelaksanaan program Swisscontact di beberapa wilayah provinsi Indonesia telah memberikan hasil yang cukup maksimal sehingga berpengaruh dalam peningkatan produksi dan ekspor biji kakao Indonesia ke luar negeri.

\section{DAFTAR PUSTAKA}

Academy of Chocolate ,2017 AoC Awards, diakses dari http://acadofchoc.com/tree-to-

bar-23-c.asp Pada 12

September 2017

Badan Pusat Statistik, 2015. Ekspor Biji Coklat Menurut Negara Tujuan Utama, 2002-2015.

Bantuan Luar Negeri Ekonomi Pembangunan, Diakses dari http://siscaporina.blogspot.com /2012/04/bantuan-luar-negeriekonomi-pembangunan.html, pada 10 Juni 2017

Barry callebaut, 2017, diakses dari https://www.barrycallebaut.com/Pada July 2017

Departemen Perindustrian, 2007. Gambaran Sekilas Industri Kakao.

E.M. Ekanayake, 2010, The effect of foreign aid on economic growth in developing countries, Journal of International Business and Cultural Studies, diakses dari http://www.aabri.com/manuscr ipts/09359.pdf pada 7 Juni $\underline{2017}$

Jelly Leviza, 2009, Tanggung Jawab Bank Dunia Dalam IMF Sebagai Subjek Hukum Internasional, Sofimedia, Jakarta.

Michael. P. Todaro, 1987, Ilmu Ekonomi Bagi Negara Sedang Berkembang I, Terj. Akademi Presindo, Jakarta.

Millenium Chalangge Accounting Indonesia, 2017, diakses dari http://www.mca-

Indonesia.go.id/en/ pada Pada

3 July 2017

MochtarMas'oed, 2008, Ekonomi-Politik Internasional dan

Pembangunan, Yogyakarta:

Pustaka Pelajar.

Muhammad nasir badu, 2015, Pemanfaatan

Dan Evaluasi Bantuan Luar Negeri Di Sulawesi Barat, Hibah Fisip Universitas Sulawesi Barat.

Kementerian Perdagangan, 2017.

"Perkembangan Ekspor

NonMigas (Sektor) Periode :2012- 2017” (online).

Diakses dari

http://www.kemendag.go.id/id/

economic-profile/Indonesia-

export- import/growth-of-

non-oil-and-gas-export-

sectoral pada 5 September 2017.

Kementerian Pertanian, 2016. Outlook Kakao: Komoditas Pertanian Subsektor Perkebunan.

Kewenangan Daerah Dalam Melaksanakan Hubungan Luar Negeri, diakses dari http://law.uii.ac.id/images/stori es/Jurnal\%2520Hukum/2\%252 OJawahir\%2520Thontoei.pdf, pada 10 Juni 2017.

Peraturan Mentri Dalam Negeri Nomor 3 Tahun 2008 Tentang Pedoman Pelaksanaan Kerjasama Pemerintah Daerah Dengan Pihak Luar Negeri

Perjanjian Internasional Oleh Daerah Sebagai Kewenangan Otonomi Daerah, diakses dari http://fh.unsoed.ac.id/sites/defa ult/files/fileku/dokumen/v10201 0\%2520noer\%2520indriati.pdf , pada 10 Juni 2017. 
PT. Krakoka, 2017 diakses dari https://www.krakakoa.com/. Pada July 2017

R. Soeprapto, 1997.Hubungan Internasionan Sistem, Interaksi, Perilaku. Jakarta: PT Raja Grafindo.

Rustian Kamaluddin, 1998, Perdagangan Dan Pinjaman Luar Negeri, Lembaga Penerbit Fakultas Ekonomi Universitas Indonesia, Jakarta.

Russett, Bruce \& Harvey Starr, 1985, World Politics. San Francisco: W.H. Freeman.

Swisscontact.org, 2017, Diakses dari http://www.Swisscontact.org/fil eadmin/user_upload/HEAD_O FFICE/Documents/Ueber_uns/ Swisscontact_Profile.pdf pada 7 Juni 2017

Statistik Perkebunan Indonesia 2014-2016 kakao, Direktorat Jenderal Perkebunan, Kementerian Pertanian, 2016

Stephen D. Krasner dalam Yanuar Ikbar, 2007, ekonomi politik internasional 2, Refika Aditama: Bandung

Syufri Yusuf, 1989, Hubungan Internasional dan Politik Luar Negeri: Sebuah Analisis Teoritis dan Uraian Pelaksanaannya, Pustaka Sinar Harapan Internasional.

UU No. 37/1999 tentang Hubungan Luar Negeri

UU NO. 32/2004 tentang Pemerintah Daerah 